\title{
Human Response to Potential Robust Climate Change around 5500 cal BP in the Territory of Bohemia (the Czech Republic)
}

\author{
Dagmar Dreslerováa ${ }^{*}$ \\ ${ }^{a}$ Institute of Archaeology, Czech Academy of Sciences, Prague, Letenská 4, 11801 Praha 1, Czech Republic
}

\section{ARTICLE INFO}

Article history:

Received: 15 May 2012

Accepted: 19 June 2012

\section{Key words}

climate change

Holocene

Neolithic

Settlement

environment

\begin{abstract}
$A B S T R A C T$
Recent research on the environmental setting of more than 3,000 Neolithic/Eneolithic sites, and of spatial distribution and shifts of various Eneolithic cultural groups, has revealed significant changes in the first half of the $4^{\text {th }}$ millennium BC. A substantial reduction in traces of settlement activities and diminution of settlement territory is apparent. There is a shift from extremely good, but environmentally varied, conditions towards the uniform areas of the driest and warmest parts of the country with the finest Chernozem soils. These changes are obviously a reaction to robust climate change from long-term stable somewhat warm and dry conditions to a colder, wetter and shifting climatic regime. This idea has been supported by the R. A. Bryson Archaeoclimate Model which reveals decreasing temperatures, increasing precipitation and the changing regime of a year march of precipitation on a regional level around $5500 \mathrm{cal}$ BP. A number of the subsequent changes in the subsistence strategies (particularly arable farming) and the settlement behaviour might be a reflection of the same change, however, cultural and social reasons for these changes cannot be excluded. Although there was a range of similar climate changes during the Holocene (supported by various proxy data as well as by the Archaeoclimate model) similar responses were not observed in the archaeological record of the later prehistoric periods.
\end{abstract}

\section{Introduction}

This contribution is dedicated to Marek Zvelebil. The range of his interests was admirably wide, from the life of hunters and gatherers through the Mesolithic - Neolithic transition and the beginning of agriculture, to the study of the ancient landscape as a whole. He used various approaches to solve archaeological themes including ethnography, linguistics, or environmental studies. In the latter respect he did not fear being accused of environmental determinism, as the example of an explanatory model for the Mesolithic-Neolithic transition in Denmark, published together with RowleyConwy (Rowley-Conwy 1984, Zvelebil, Rowley-Conwy 1984) demonstrates. The expressions flux and transition were often used in his work but may also be used in order to characterise Marek Zvelebil himself.

Landscape, environment and flux will also be the subject of this article. It attempts to answer the question as to whether the observed change in spatial distribution of archaeological

"Corresponding author. E-mail: dreslerova@arup.cas.cz evidence from the Neolithic and Eneolithic (in the sense of the Middle and Late Neolithic in NW Europe, ca. 4200$2200 \mathrm{BC}$ ) might have been caused by a change in climate or whether this phenomenon was independent from external forces and a result of cultural factors.

The previous climate, as the most important agent influencing the alteration of all other parts of an environment, is the subject of many scientific disciplines, although the outcomes are, despite tremendous efforts, still somewhat unsatisfactory. The main reasons for this are: the complexity of the climate system as such, the regionality of the climate, the short history of its direct instrumental measurement, the evaluation of the climatic parameters in relative terms (e.g. wetter, drier), the varying sensitivities of the proxies, and the difficulties of their more precise dating. Previous allegations can be illustrated by comparing proxy data supported by warmer/drier and cooler/wetter climate phases at ca. 6000 cal BP in Britain and north-west Europe (Schulting 2010) or in the eastern Mediterranean and adjacent regions over the past 6000 years (Finné et al. 2011). In both cases the proxies from the same period of time vary enormously in spite of the relative geographical proximity of the areas 


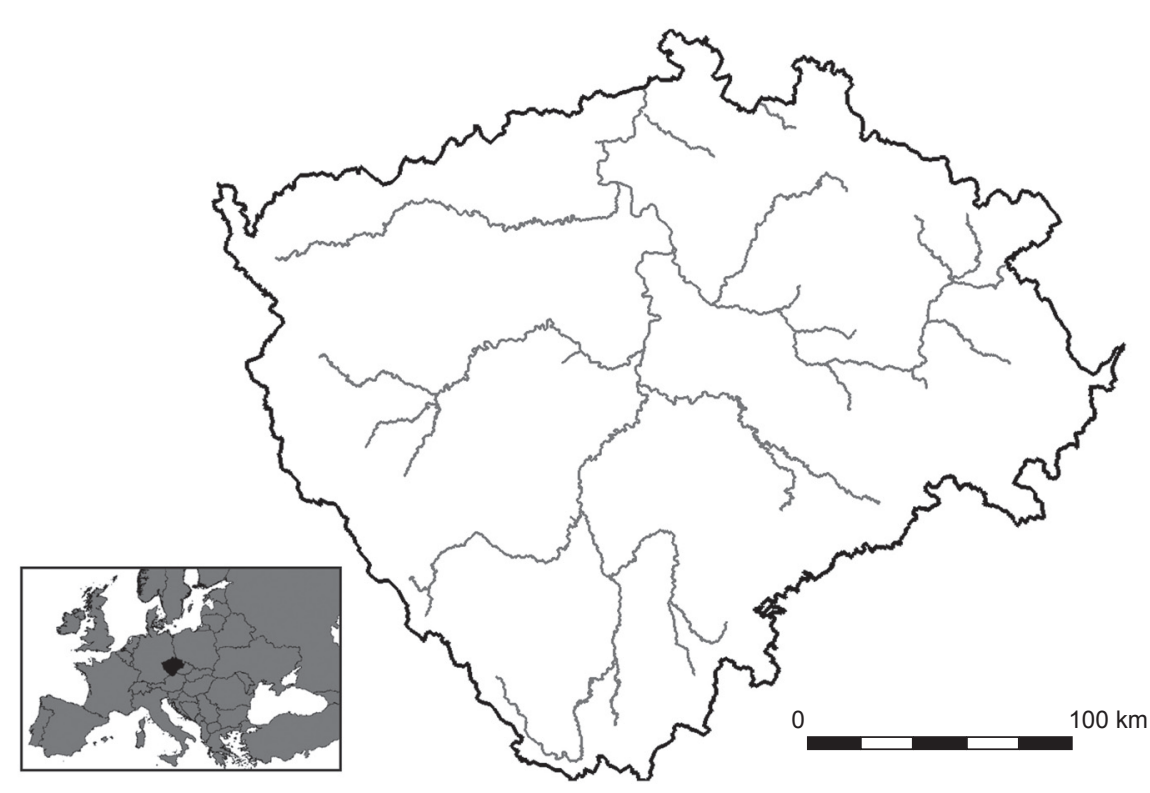

Figure 1. Map of discussed area (Bohemia, Czech Republic).

under study. There is equivalent evidence for either warmer/ drier or cooler/wetter climates in the same time span. Similar situations elsewhere in Europe are illustrated by Table 1.

Apart from the issues mentioned above, the reconstruction of the previous climate in Bohemia is complicated by its geographical location on the border between two climate regimes, the Atlantic and the Continental one, which in addition have changed in the past (e.g. Crumley 1995). Holocene climates on the scale of the European continent differ significantly; warming and cooling trends may be different and even opposed in Northern, Central, and Southern Europe as demonstrated by Davis et al. (2003). They analysed data from almost 500 European pollen profiles. In their study, Europe was divided into six segments, each one having a rather different run of the Holocene average summer and winter temperatures. The modelled boundaries of central-west and central-east European segments (with diverse climatic regimes) take place at 15 meridian in the central part of Bohemia. This situation significantly worsens the possibility of taking over not only climatic data from geographically distant regions but also from the Bohemian basin itself. Due to the lack of high resolution climate proxies from this space, climate modelling becomes an important tool for climate reconstruction in the past.

Human response to possible environmental change is still poorly known. The most commonly reported ways in which society (hunters and gatherers and farmers may react in different ways) responds to such a change (respectively the change in the raw material base) are: spatial mobility, relocation to other sources of subsistence or to more favourable areas, extension or diminishment of the exploited territory, and technological changes (Halstead, O'Shea 1989, Schibler et al. 1997, Dincauze 2000). The observed spatial change in the Bohemian archaeological record corresponds with the above-mentioned possible responses and provides an ideal opportunity to test whether the supposed alteration of the climate regime might be a cause of changing settlement behaviour.

\section{Materials and Methods}

Elevation, temperature, precipitation, growing season, and soils rank among the usual environmental parameters investigated in connection with settlement activities. The latter mentioned variables are causally related to the first one which presumably played the most important role in the human decision as to where to settle (Kočár et al. in prep.). The altitudinal range is rather insignificant in the case of this study since all Neolithic and Eneolithic archaeological cultures (apart from the Cham culture in Western Bohemia), settled in a territory below $350 \mathrm{~m}$ a. s. 1. within which individual positions at the lowest altitude were once again preferred (Dreslerová 2011). The relationship between settlement and environmental conditions is assessed on the basis of the present day data. It is assumed that even if the climate varied in the past, it varied according to the conditions in today's climate regions.

Archaeological data in the form of circa 3,000 records concerning Neolithic/Eneolithic sites has been obtained from the Bohemian archaeological database, version 2009 (Archeologická databáze Čech 2009). All the individual and purely dated records were removed from the database, but in spite of this fact it may include certain discrepancies primarily due to the inaccurate location of a site or insufficient description of the archaeological finding. For this reason a cadastre (as a substitute unit for the settlement area serving as the space of all settlement activities) was chosen as the basis for the analysis. The database covers an area of 52,783 $\mathrm{km}^{2}$ divided into 9,558 cadastres. The average cadastral size is $5.5 \mathrm{~km}^{2}$. Each cadastre is represented by only one record of a given culture/period (regardless of the type of activity). The result does not reflect the quantitative aspect of the settlement, only the spatial extent of each culture/period.

Climate and soil properties are also related to the entire cadastre. Climate has been characterised by the mean annual precipitation and the temperature derived from the Climate 


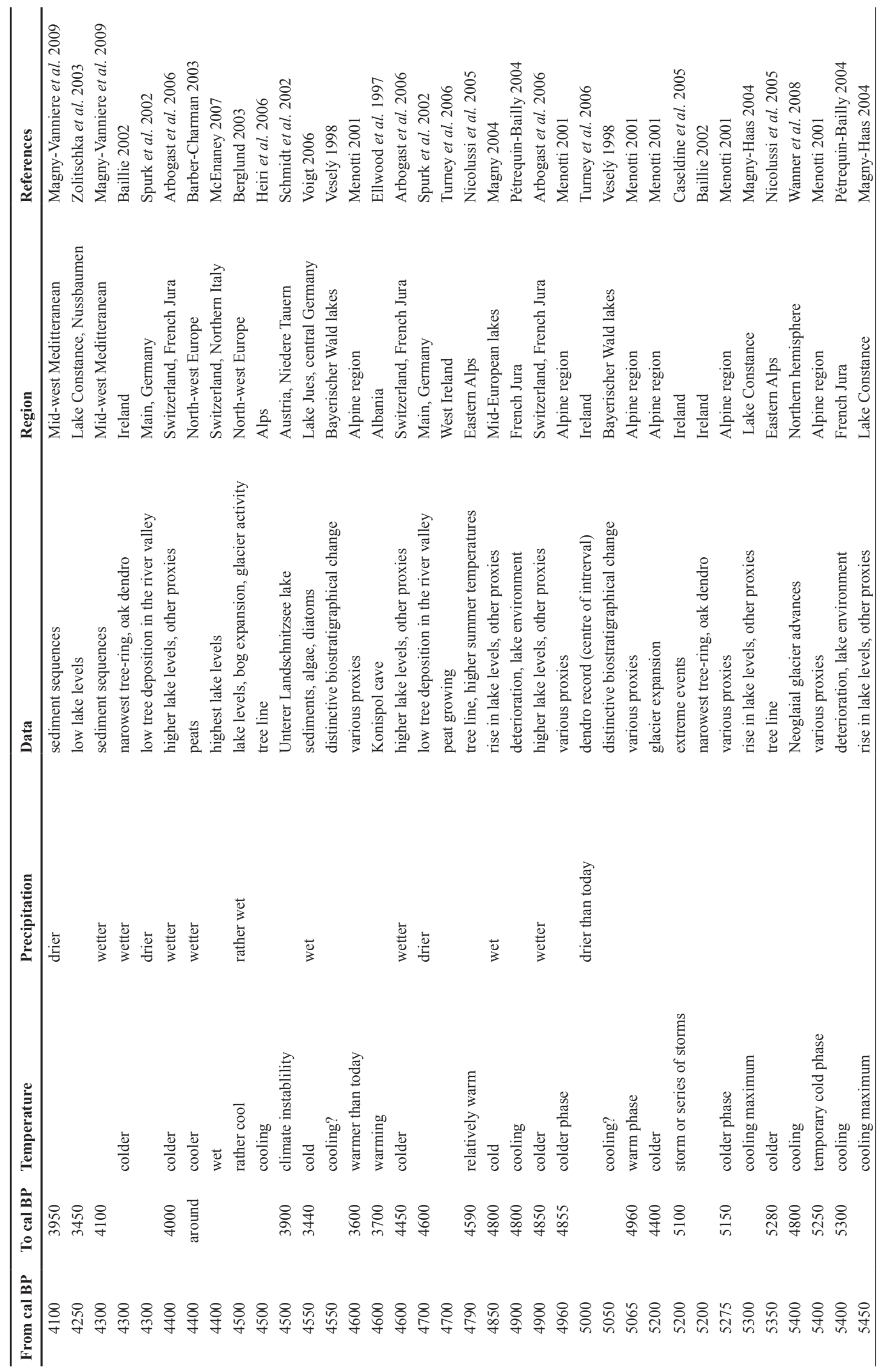




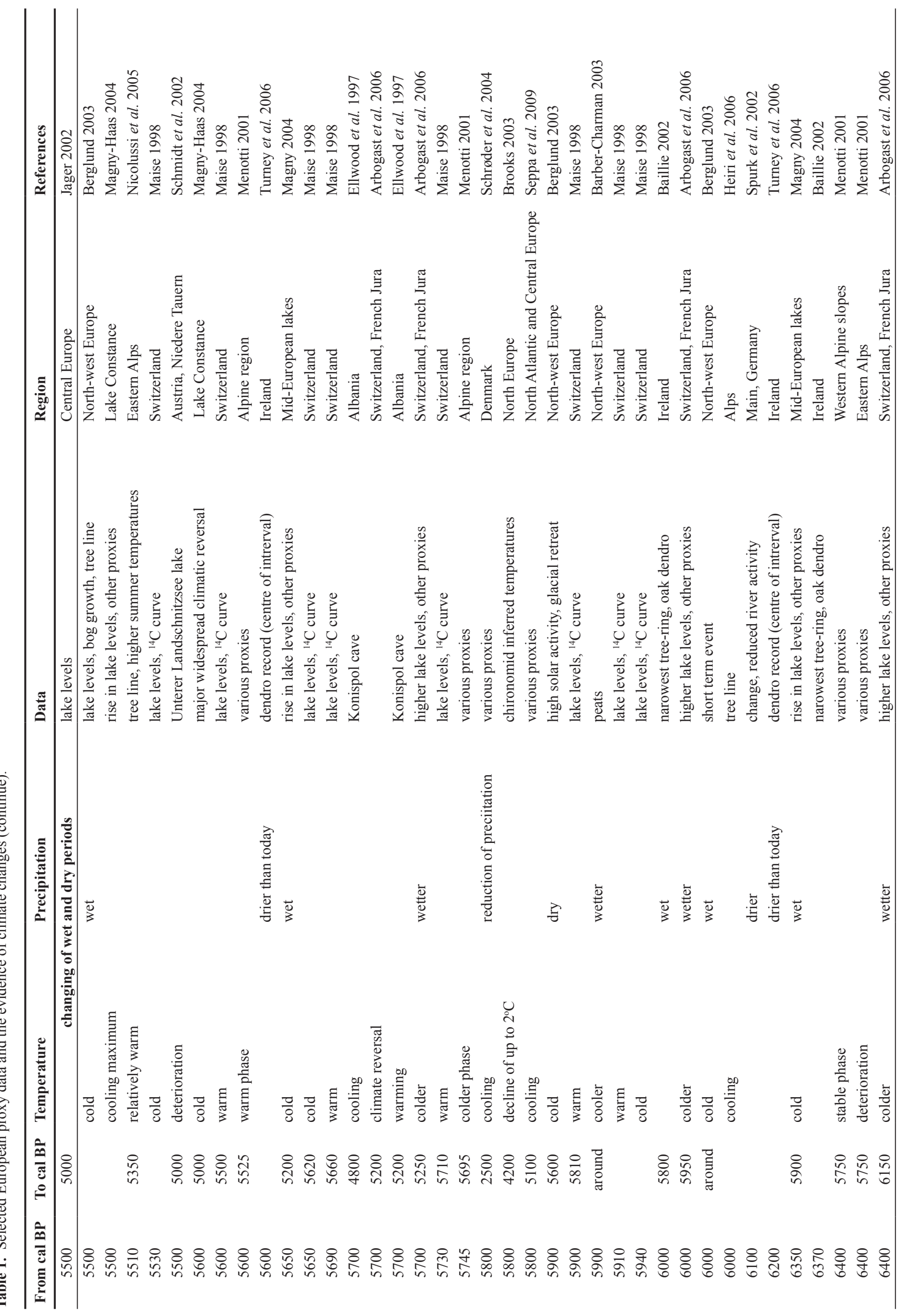




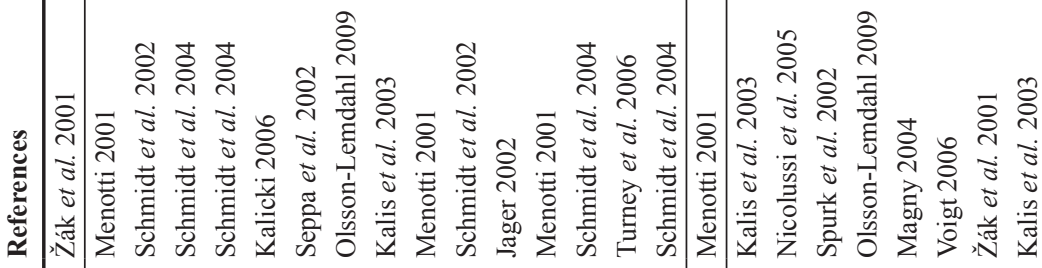

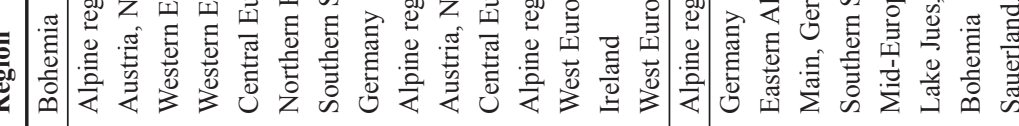

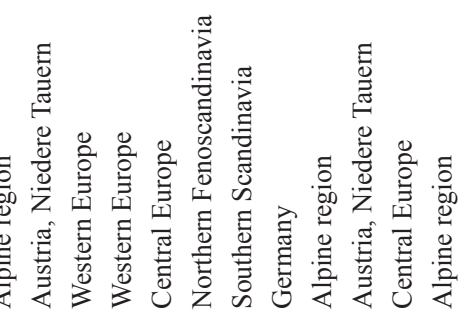

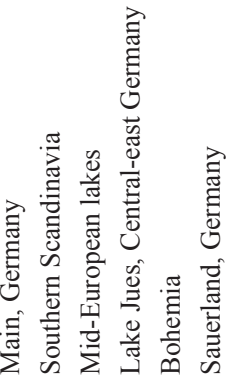

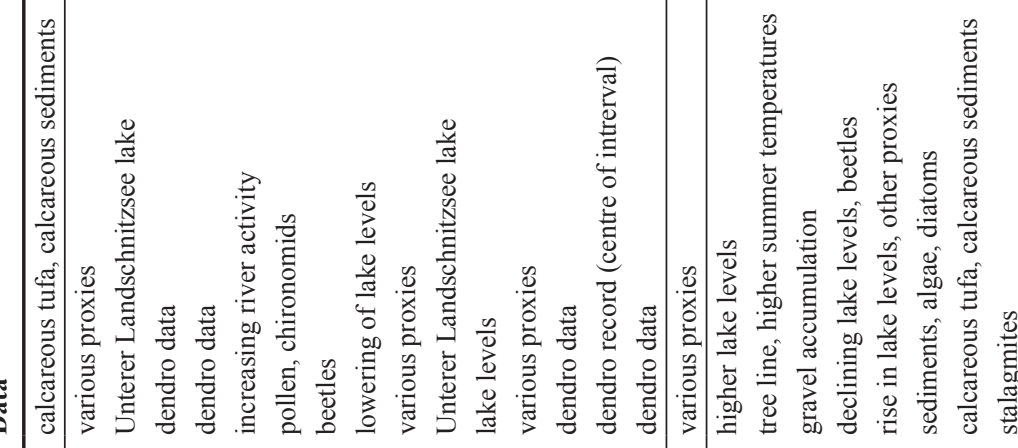

를

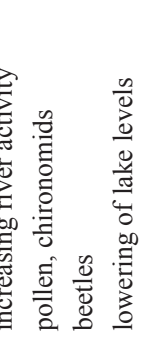

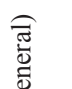

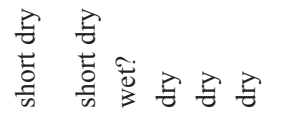

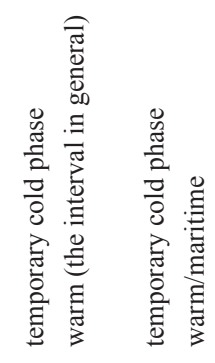

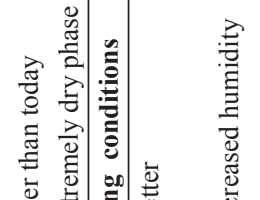

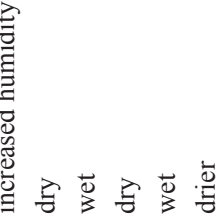

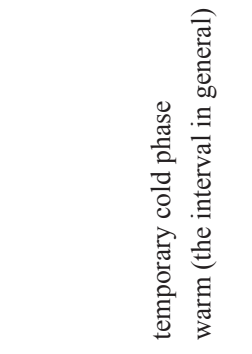


Atlas of the Czech Republic (Tolasz et al. 2007) and by the combined value of the length of the growing season and the annual temperature and precipitation according to The Climate Regionalisation of the Czech Republic (Moravec, Votýpka 2003). Soils have been taken from the publication Soil in the Czech Republic (Hauptman, Kukal, Pošmourný, eds. 2009).

Past climate has been modelled using the Archaeoclimatology Macrophysical Climate Model (MCM). It was developed in the mid-1990s by R. A. and R. U. Bryson. It is in essence a heat budget model predicated on orbital forcing, variations in atmospheric transparency, and the principles of synoptic climatology. The results provide estimates of the mean monthly temperature and precipitation at a 100 year interval for a specific locality/region without using any proxy-data (Bryson, Mc Enaney de Wall 2007, Dreslerová 2008, Dreslerová 2011). The presented model of potential evapotraspirationwasobtainedusing the Thornthwaitemethod (Thornwaite 1948; http://ponce.tv/onlinethornthwaite.php) on the basis of meteorological data from the Prague-Karlov station (annual monthly temperatures and precipitation from 1960-1990).

\section{Results and discussion}

The relationship between settlement, temperature and precipitation is demonstrated by Figures 2, 3 and 4. There is a moderate preference for areas with the highest temperatures and the lowest precipitation in the Eneolithic (apart from the Cham culture) as compared with the Neolithic, although presumably the low precipitation was more important than the high temperature (Figure 4).

The relationship between the length of the growing season, temperature and precipitation, illustrated by Figure 5, reveals a preference for the regions with the longest growing season and the lower precipitation to those with the same length of growing season but higher precipitation.

\subsection{MCM modelled climate parameters}

The MCM model indicates that between circa $7500 \mathrm{cal} \mathrm{BP}$ and circa 5500 cal BP the values of potential evapotranspiration (PET) might exceed the rainfall in the growing season, which means that the conditions were relatively drier and warmer. There was a slight fluctuation around 6300 cal BP (Figures 6, 7). Around 5500 cal BP there was a significant change in the regime of precipitation, and rainfall prevailed over evaporation - the climate became relatively more humid and colder. This mode might have lasted to circa 3400 cal BP with a slight warming and drying around $4950 \mathrm{cal}$ BP and a cooling and humidification around $4300 \mathrm{cal}$ BP.

The model of the march of the year precipitation (Figure 8) demonstrates a pronounced change on a regional level around 5500 cal BP. Until then precipitation during the summer months prevailed, with a steady rainfall throughout the rest of the year. The change consisted of a shift in rainfall and also richer precipitation into the spring months. This march of the year precipitation has remained up to the present.
The modelled climate humidification and cooling after 5500 cal BP corresponds well with the spatial distribution of the traces of Neolithic-Eneolithic settlement activities. Neolithic cultures occur in the warmest areas, but also extend beyond them. Concerning precipitation, wetter areas are settled and in comparison to the later period, greater ecological diversity is tolerated. The process of settlement contraction in the warmest and mainly driest areas began as early as the early Eneolithic but culminated in the Middle Eneolithic and the Bell Beaker periods.

\subsection{The relationship between settlement and soils}

A description or estimation of prehistoric soil conditions is one of the most difficult tasks. In contrast to climate, soils have been heavily influenced by human activities at least since the beginning of agriculture and over the past 7000 years erosion and accumulation processes might have changed topography and soil cover entirely (Lang, Bork 2006, Leopold, Völkel 2007, Zádorová et al. 2008). Due to various forms of cultivation, soils have been either ameliorated or degraded for millennia. Moreover, the rate of natural processes e.g. acidification and nutrient leaching during the interglacial, has been rather insufficiently known as well as the evolution of Czernozems in certain European regions (Eckmeier et al. 2007).

Soils are assessed according to present day conditions, despite the fact that the current soil quality and to some extent soil cover do not correspond to those in prehistory. Nevertheless, the macro-scale approach used in this study enables us to compare entire regions and soils on a typelevel. We expect that soils have changed on a sub-type level (e.g. Czernozem to Modal or Arenic Czernozems etc.), but since their origin have stayed in the same category of soil types.

Both Neolithic and Eneolithic cultures (apart from the Cham culture) settled almost exclusively in lowland areas below $350 \mathrm{~m}$ a. s. 1 characterised by loess subsoil covered by Chernozems and Luvisols, e.g. soils considered as having the best agricultural quality. The Neolithic LBK and STK cultures were evenly spread across both Chernozem and Luvisol areas. The gradual change of preferences towards purely Chernozems regions began in the Proto and Early Eneolithic. Over the course of the Eneolithic this trend increased, being the most remarkable in the Bell Beaker period. This stage terminated with the older part of the Early Bronze Age.

Regarding the perspective of climate change, the preference of Chernozem areas could be explained by the increased humidity over the previous period. Chernozems are situated in the driest parts of the country and in comparison with Luvisols, have a worse water balance regime and are susceptible to drying out.

The MCM climate concept is in striking contrast to the traditional Holocene climate scenario in Bohemia based on lithology, creation of calcareous tufa deposition and mollusc evidence. The results obtained from the section in the Svatý Jan pod Skalou, Bohemian Karst region, indicate a 


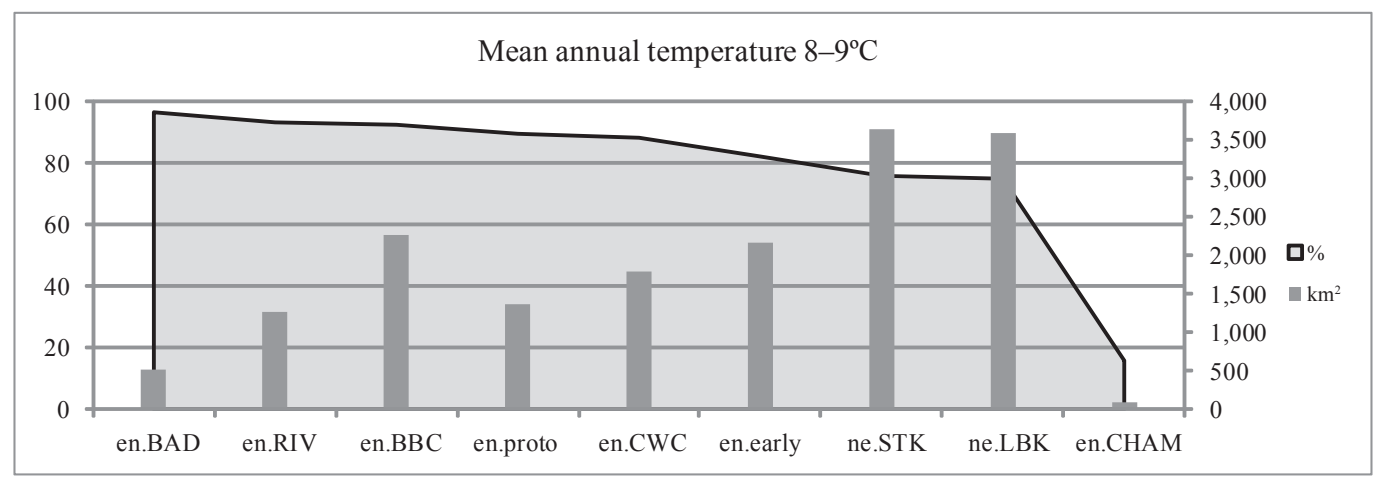

Figure 2. The relationship between archaeological cultures/periods and regions with the highest mean annual temperature. The percentage expresses the proportion of area occupied by a given culture/period in this zone. Km2 expresses the area of occupied cadastres situated in this zone. ne. LBK - Neolithic Linearband pottery culture, ne.STK - Neolithic Stichband pottery culture, en.proto - Proto Eneolithic, en.early - Early Eneolithic (mostly Funel Beaker culture), en.bad - Baden culture, en. cham - Cham culture, en.riv - Řivnáč culture, en. CWD - Corded Ware culture, BBC - Bell Beaker culture.

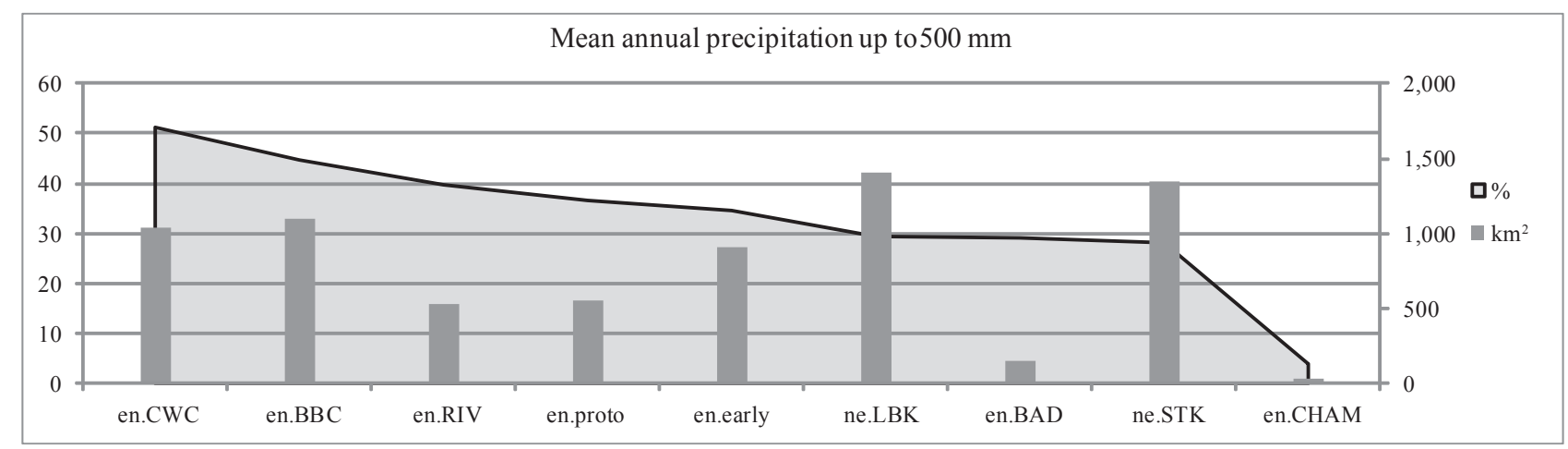

Figure 3. The relationship between archaeological cultures/periods and regions with the lowest mean annual precipitation. For a further explanation see the description in Figure 1.
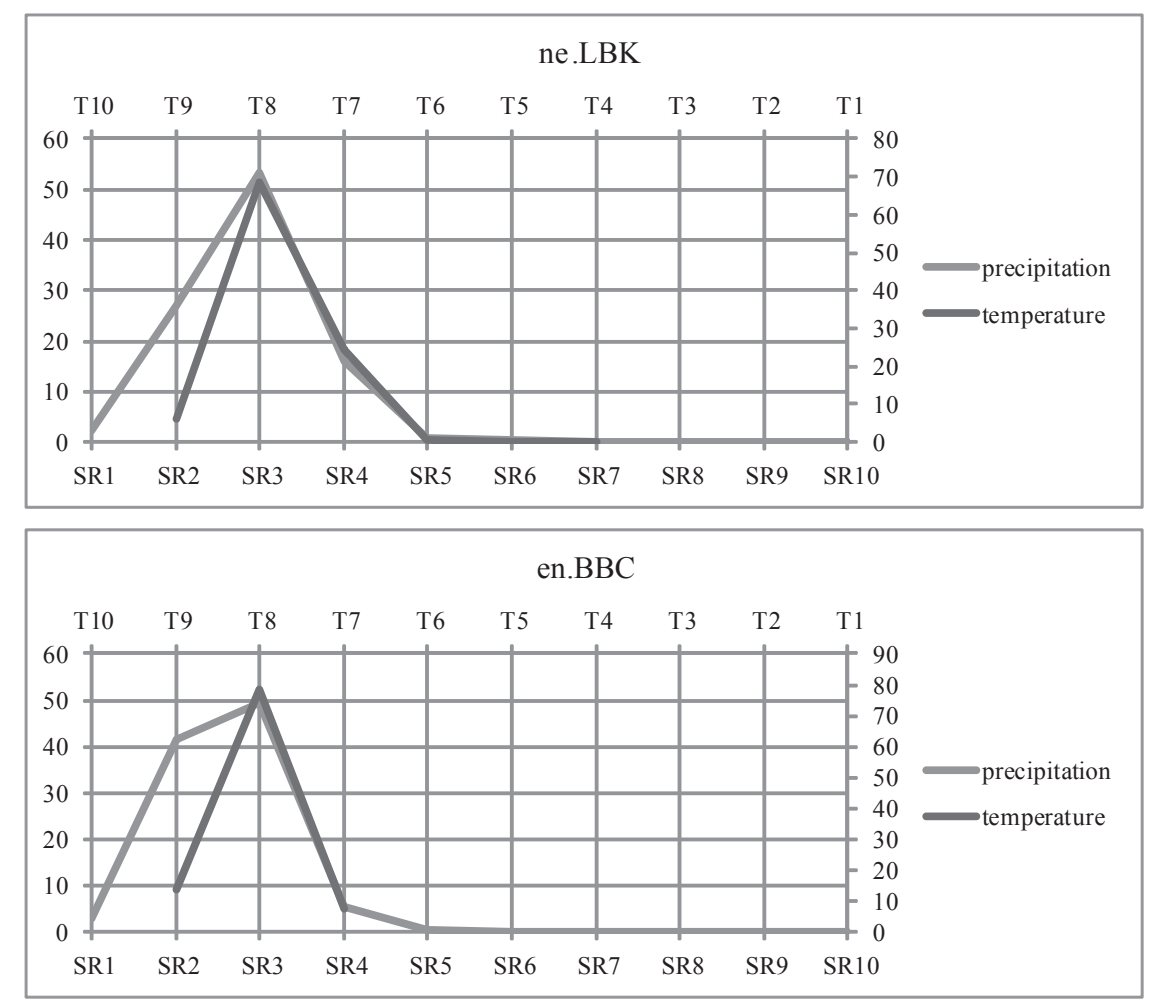

Figure 4. A comparison of the relationship between precipitation (\%, left axis) a temperature (\%, right axis) on the sites of the Neolithic LBK and Eneolithic Bell Beaker cultures. It shows a preference for drier conditions in BBC. Classes of and average yearly temperatures (in $\left.{ }^{\circ} \mathrm{C}\right)$ : $\mathrm{T} 6-5-6, \mathrm{~T} 7-6-7, \mathrm{~T} 8-7-8, \mathrm{~T} 9$ $-8-9, \mathrm{~T} 10->9^{\circ} \mathrm{C}$. Classes of average yearly precipitation (in mm): SR $1-<400$, SR2 $-400-500$, SR3 $-500-600$, SR $4-600-700$, SR $5-700-800 \mathrm{~mm}$. 

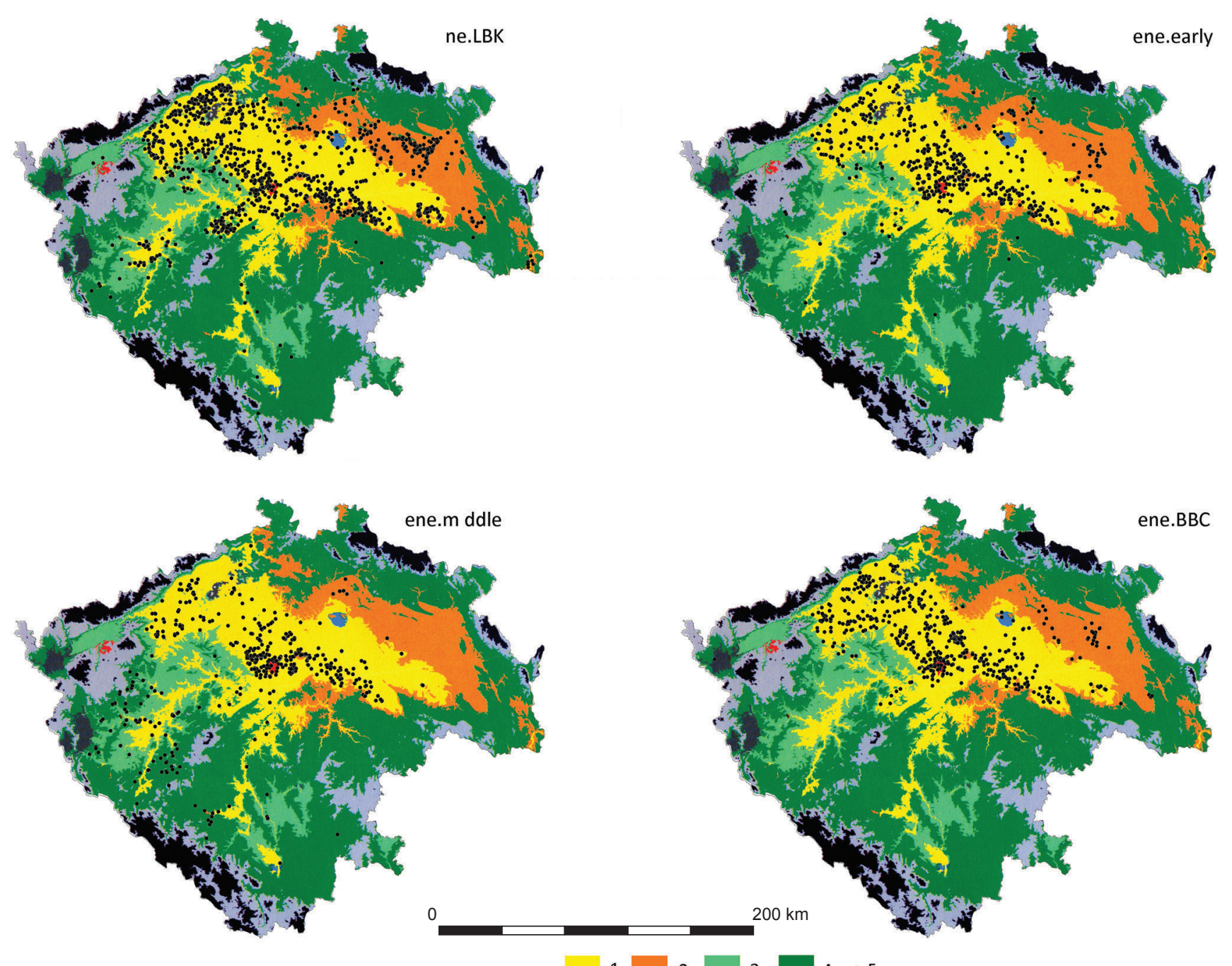

ene.m ddle
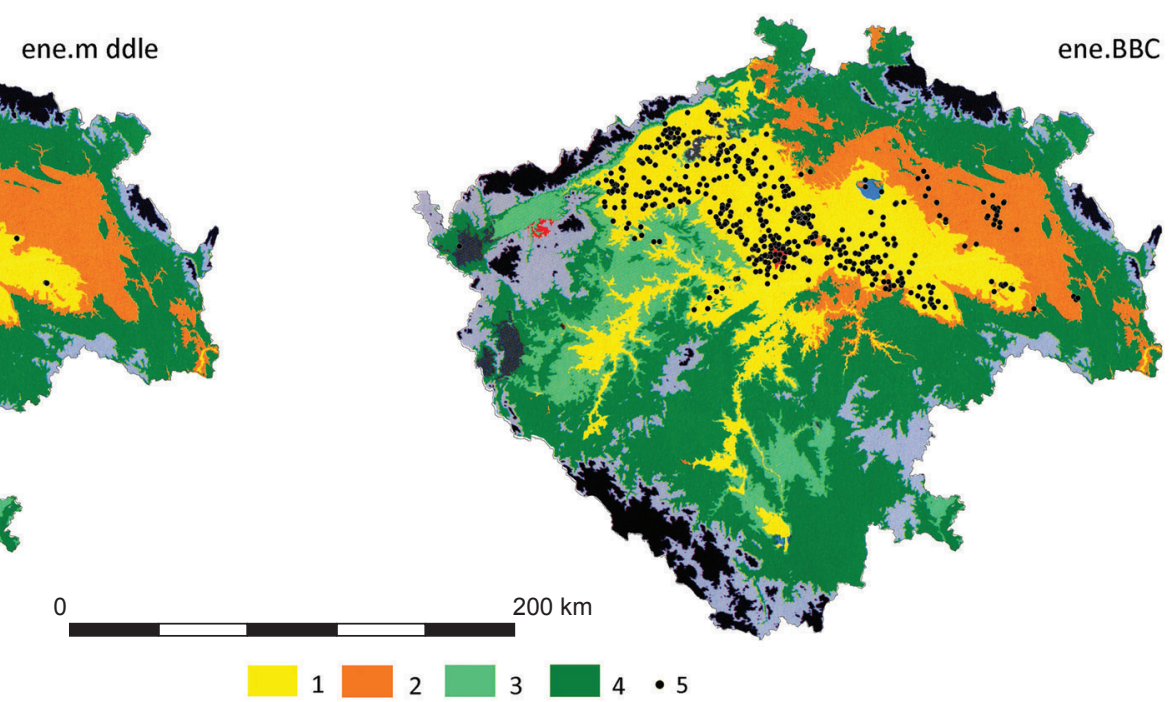

Figure 5. The relationship between archaeological cultures/periods and the growing season, temperatures and precipitation. Climate regionalization after Moravec, Votýpka 2003. 1 - annual temperature $>10^{\circ} \mathrm{C}$ from 160 to 177 days, annual precipitation $<580 \mathrm{~mm}$; droughts above 22 days; 2 - annual temperature $>10^{\circ} \mathrm{C}$ from 160 to 177 days, annual precipitation $<580 \mathrm{~mm} ; 3$ - annual temperature $>10^{\circ} \mathrm{C}$ from 142 to 159 days, annual precipitation $<580 \mathrm{~mm}$; droughts above 22 days; 4 - annual temperature $>10^{\circ} \mathrm{C}$ from 142 to 159 days, annual precipitation $>580 \mathrm{~mm} ; 5$ - archaeological sites. For a further explanation see the description in Figure 1. Image by Č. Čišecký.

rather warm and wet climate optimum between $9500-6500$ cal BP. The mean annual temperatures for this period were said to be only slightly higher than during the later period. Annual precipitation was higher and an oceanic-type climate prevailed with smaller temperature differences between winters and summers. The phase after approximately 6500 years BP, spanning about 4000 years, is characterized by short rapid oscillations of dry and wet periods. In several sections located in the Bohemian Karst, up to 5 dry oscillations can be identified. The duration of these dry oscillations is not precisely known (Žák et al. 2002).

The obvious discrepancy in both climate reconstructions needs further examination. Nevertheless, the relationship between spatial distribution of the prehistoric settlement and observed present day temperature, precipitation and soil parameters supports the idea of the "climate optimum" being warmer and drier. A warm and dry Atlantic period (in the sense of Firbas 1949; 1952; ca. 7400-5300 cal BP) has also been reconstructed on the basis of sediment characteristics and changes in algal assemblages from Lake Jues, Harz Mountains, Germany. Warm summers and mild winters ended ca. 4550 cal BP and were followed by a cool humid period with changeable summers (Voight 2006). Warm and dry periods between 7000 and $5000 \mathrm{cal} \mathrm{BP}$ were detected in the sediments from a high mountain lake (Unterer Landschitzsee) in the Central Austrian Alps (Schmidt et al. 2002). Additionally, in southern Sweden numbers of aquatic and hygrophilic beetles indicate dry conditions between circa 5000 and 3000 cal. BC (Olsson, Lemdahl 2009).

Abrupt climate change at circa $5500 \mathrm{cal}$. BP is documented by a vast amount of climate proxies worldwide (Schuman 2012). Numerous references concerning Mid-Holocene climatic reversal and hydrological changes were collected by Magny-Haas (2004), who also demonstrate the evidence 


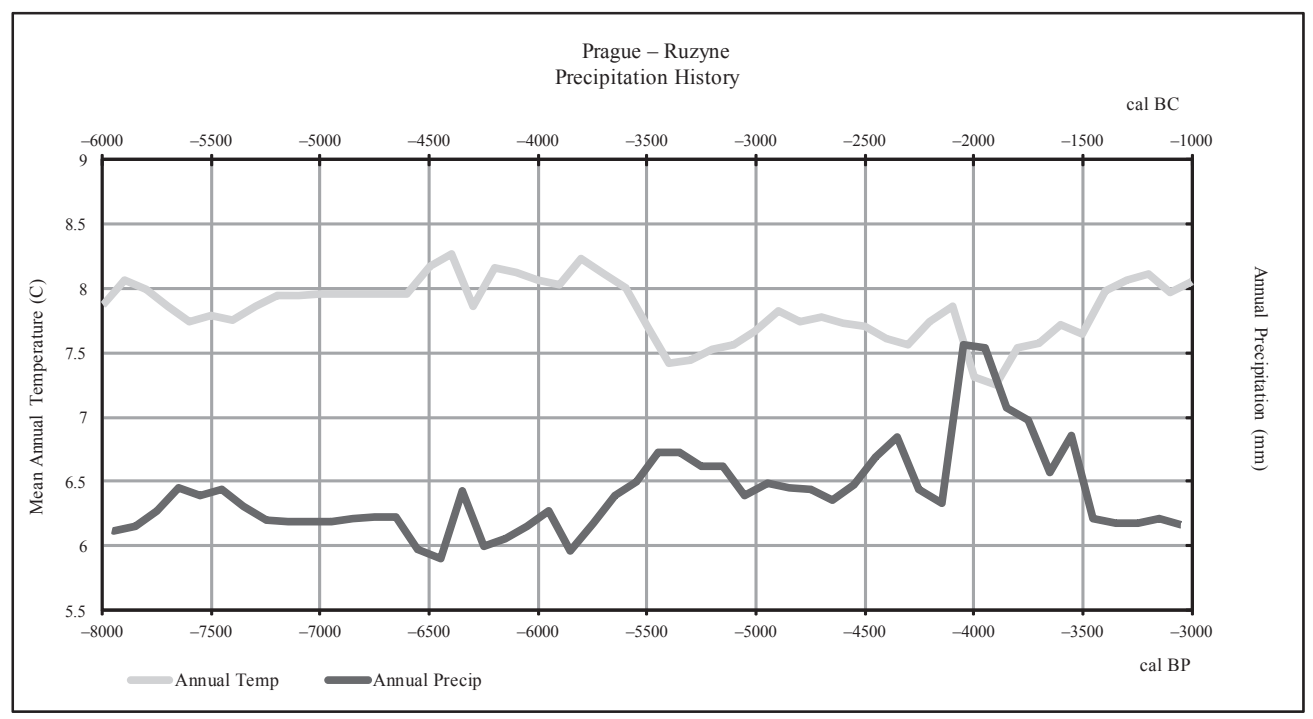

Figure 6. Potential mean annual temperature and precipitation in the growing season between 8000-3000 cal BP for Prague - Ruzyně. Modelled by Mária Hajnalová.

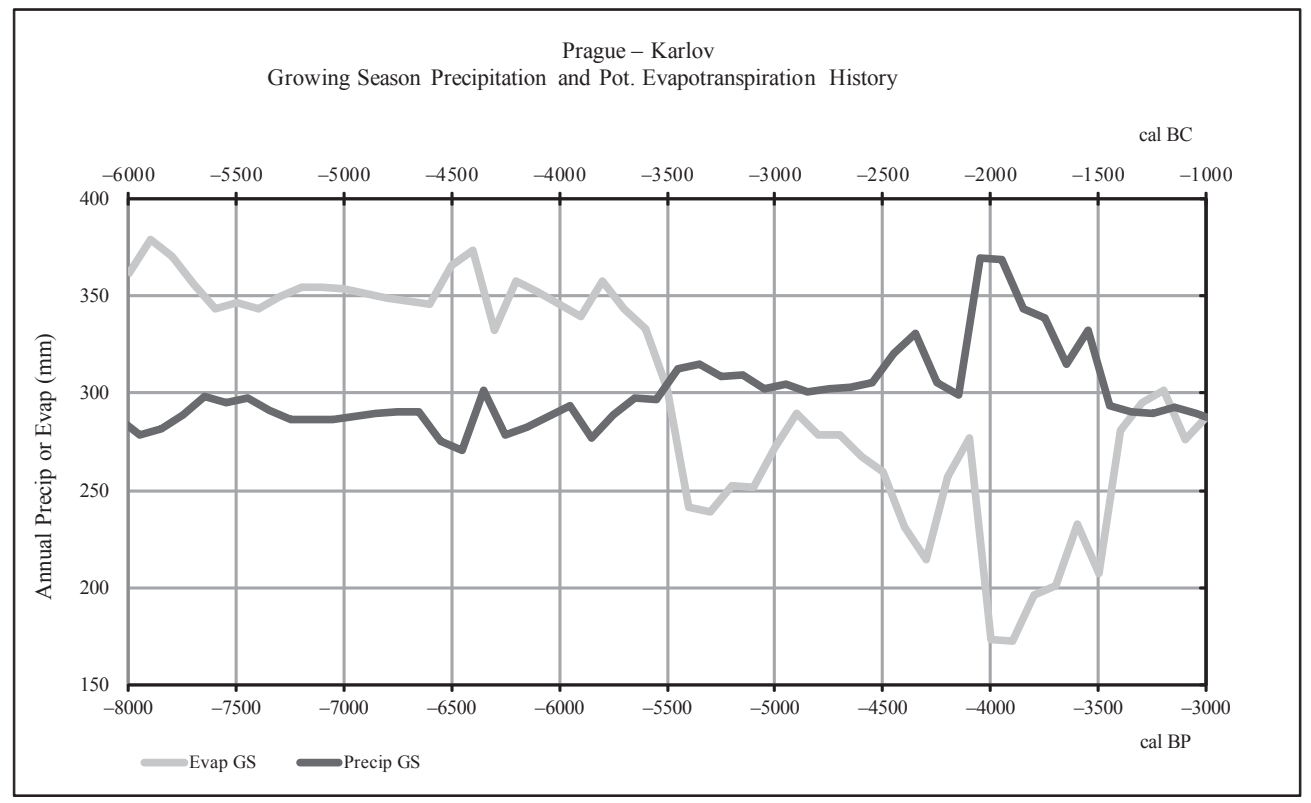

Figure 7. Potential evapotranspiration in the growing season between 8000-3000 cal BP for the Prague - Karlov. Modelled by Mária Hajnalová.

of abrupt climate change at 5550-5300 cal. years BP at Arbon Bleiche, Lake Constance, Switzerland. Also in the Swiss Northern Alps, for instance, the pollen-inferred July temperature and annual precipitation suggest a trend toward a cooler and more oceanic climate starting at about $5500 \mathrm{cal}$. BP (Wick et al. 2003). Changes towards wetter and cooler conditions are also recorded in the Swiss and Jurassian lakes (Magny et al. 2006, Arbogast et al. 2006), in the North Ireland dendro record (Turney et al. 2006), or in NW Europe generally (Berglund 2003). Climate change at ca. 5400 cal BP is also recorded in the Mediterranean, but contrary to Central and north-west Europe the period between 6000-5400 cal $\mathrm{BP}$ is primarily wetter than average and $5400-4600 \mathrm{cal} \mathrm{BP}$ is still mainly wetter than average, but less so than the previous period (Finné at al. 2011, 3169).

The effort to evaluate the impact of the palaeoclimate and its changes on the evolution of previous human societies leads to certain problems. On the one hand, climate phenomena are limited to distinct, sometimes even extremely small areas. This fact complicates the use of proxies from other regions. On the other hand, the knowledge of human behaviour in the past is limited. This was not necessarily driven strictly by economic and practical aspects of existence. The current concepts are primarily derived from an assumption that man is, and always was, a rational being, and thus has dealt with climate changes in ways similar to the ways we do so today. 

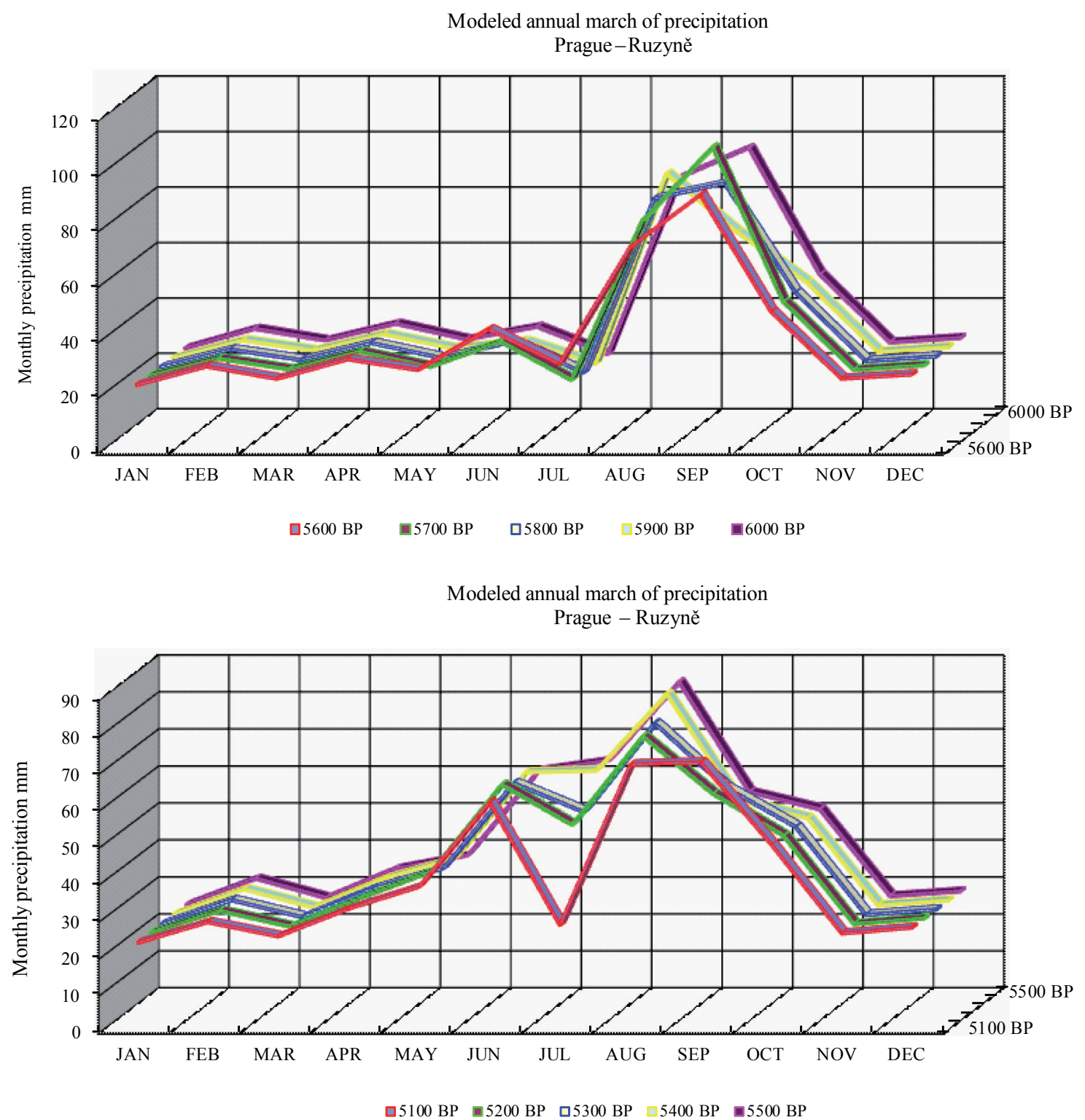

Figure 8. Changing regime of a year march of precipitation around $5500 \mathrm{cal} \mathrm{BP.} \mathrm{Modelled} \mathrm{by} \mathrm{Linda} \mathrm{Scott-Cummings.}$

This assumption could be false. Moreover, as the historical examples demonstrate, climate changes (or abrupt weather events) are not usually the actual and/or the only cause of historic events. They usually serve as a trigger mechanism at a time when problems in society accumulate. If the society was in a secure state, the reaction to climate change/weather events would be much less dramatic and thus usually not recognisable in archaeological records.

This, however, does not seem to be the case in the abovementioned events at circa 5500 cal BP. In the Eneolithic, social and cultural instability took place, manifested by relatively rapid alternation of archaeological cultures and their different settlement, funeral and subsistence strategies. It was a period of "secondary product revolution" albeit this concept is no longer valid in its original meaning (Grenfield 2010). Society was susceptible to changes which became evident in the reduction of settled areas towards the most fertile dry Chernozem regions (Dreslerová 2011) or in innovations to farming, e.g. the beginning of barley cultivation (Kočár, Dreslerová 2010), animal traction and changes in animal husbandry.

The proportion of bred animals changed in the Protoeneolithic Lengyel period (circa 6600-6200 cal BP) and in the middle Eneolithic (circa 5400-4800 cal BP) towards a greater importance of sheep/goats in comparison with other periods in which cattle entirely predominated. At the same time, an increasing percentage of wild animal bones in the archaeozoological assemblages indicates the rising importance of hunting in the proto and middle Eneolithic (Kyselý 2012). A number of these events seem to be related to robust climate change from a long-term stable and warmer and drier climate to less stable wetter and colder conditions around $5500 \mathrm{cal} \mathrm{BP}$. 

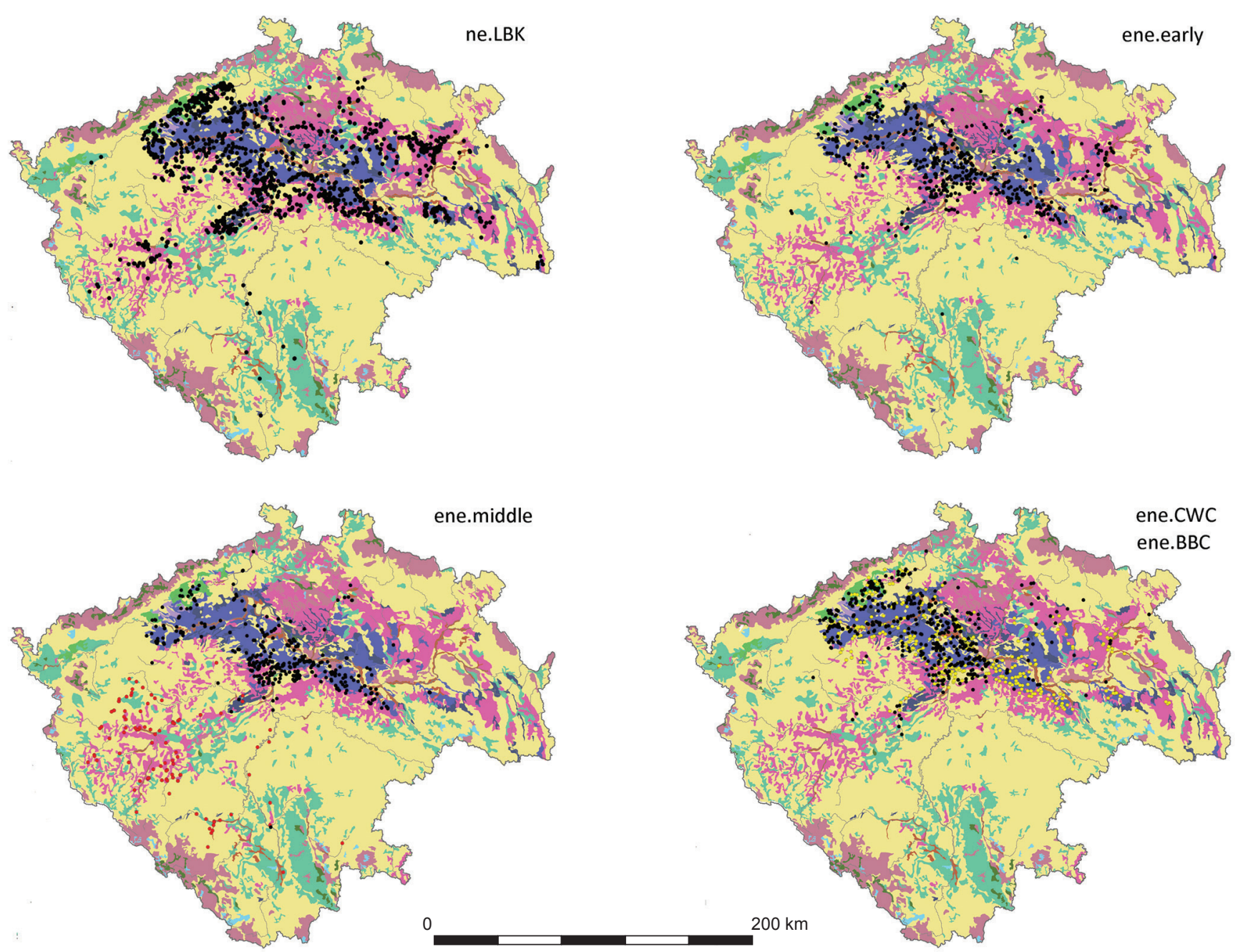

ene.middle
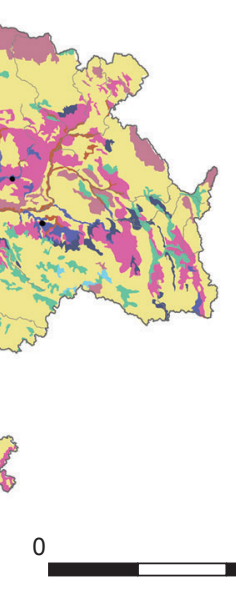

$200 \mathrm{~km}$

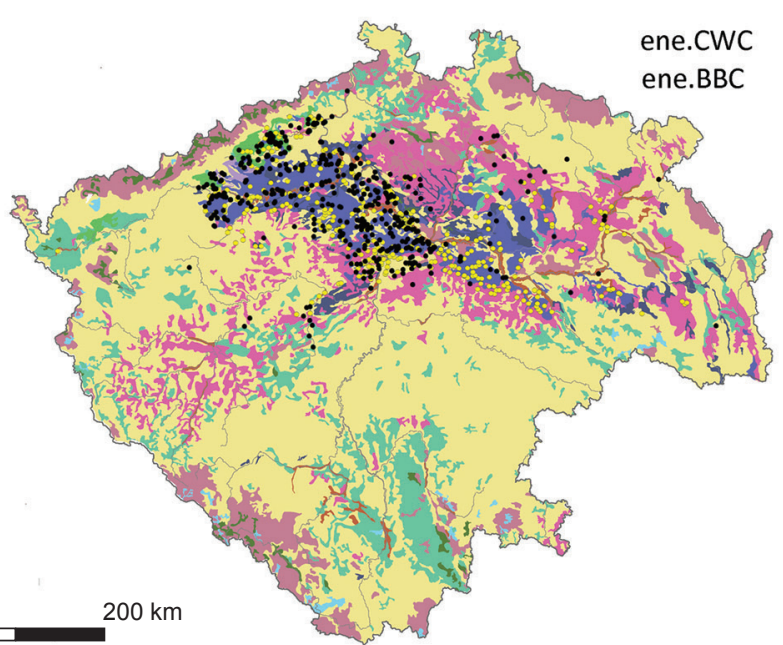

$1 \square 2 \square 3 \square 4 \cdot 5 \circ 6 \cdot 7$

Figure 9. The relationship between archaeological cultures/periods to soils. Soil maps after Hauptman, I., Kukal, Z., Pošmourný, K. (Eds.) 2009. 1 Czernozems; 2 - Luvisols; 3 - Kambisols, 4 - Stagnosols, 5 - archaeological sites; 6 - archaeological sites from Corded Ware culture; 7 - archaeological sites from Cham culture. For a further explanation see the description in Figure 1. Image by Č. Čišecký.

\section{Conclusions}

Recent research on the environmental setting and spatial distribution of the Bohemian Neolithic and Eneolithic settlement has revealed significant changes in the first half of the $4^{\text {th }}$ millennium BC. They consist of a substantial reduction in traces of settlement activities and the diminution of the settlement territory. There is also an observable shift

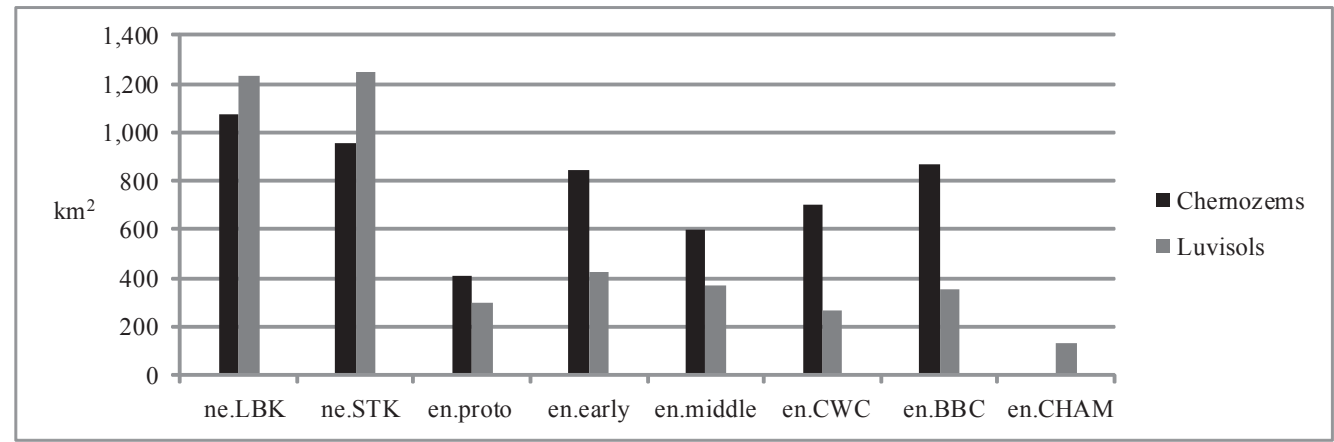

Figure 10. The relationship between archaeological cultures/periods to Chernozems and Luvisols. $\mathrm{Km}^{2}$ expresses the total area of given soils within occupied cadastres. For a further explanation see the description in Figure 1. 
from extremely good, but environmentally varied conditions towards the uniform areas of the driest and warmest parts of the country with the finest Chernozem soils. These changes are obviously a reaction to robust climate change from longterm stable rather warm and dry conditions to colder and wetter and shifting climatic regime over the course of the sixth millennium BP. This idea has been supported by the R. A. Bryson Archaeoclimate Model which reveals decreasing temperatures, increasing precipitation and the changing regime of the year march of precipitation on a regional level around 5500 cal BP. A number of the subsequent changes in the subsistence strategies (particularly arable farming) and the settlement behaviour might be a reflection of the same change, however, cultural and social reasons for these changes cannot be excluded.

Although there was a range of similar climate changes during the Holocene (supported by various proxy data as well as by the Archaeoclimate model) similar responses were not observed in the archaeological record for the later prehistoric periods (Dreslerová 2011). It seems that the reliance of society on the climate and other environmental factors was more significant in the older part of prehistory and was losing its importance over the course of the Early Bronze Age at the latest.

\section{References}

ARBOGAST, R. M., JACOMET, S., MAGNY, M. 2006: The significance of climate fluctuations for lake level changes and shifts in subsistence economy during the Late Neolithic (4300-2400 BC) in Central Europe, Vegetation History and Archaeobotany 15/4, 403-418.

Archeologická databáze Čech, verze 2009, Archeologický ústav Praha AV ČR. Archaeological databases of Bohemia, version 2009, Institute of Archaeology, Academy of Sciences of the Czech Republic, Prague.

BAILLIE, M. G. L., BROWN, D. M. 2002: Oak dendrochronology: some recent archaeological developments from an Irish perspective, Antiquity 76, 497-505.

BARBER, K.E., CHARMAN, D. J. 2003: Holocene Palaeoclimate Records from Peatlands. In: Mackay, A., Battarbee, R., Birks, J. (Eds.): Global Change in the Holocene. Arnold, London, 210-226.

BERGLUND, B. E., 2003: Human impact and climate changes-synchronous events and a causal link? Quaternary International 105 (2003), 7-12.

BROOKS, S. J. 2003: Chironomid Analysis to Interpret and Quantify Holocene Climate Change. In: Mackay, A., Battarbee, R., Birks, J. (Eds.): Global Change in the Holocene. Arnold, London, 328-341.

BRYSON, R.A., McENANEYDeWALL, K. (Eds.) 2007: A paleoclimatology workbook: high resolution, site-specific, macrophysical climate modeling. The Mammoth Site of Hot Springs, Hot Springs.

CASELDINE, C., THOMPSON, G., LANGDON, C. 2005: Evidence for an extreme climatic event on Achill Island, Co. Mayo, Ireland around 5200-5100 cal. yr BP, Journal of Quaternary Science 20, 69-178.

CRUMLEY, C. L. 1995: Cultural implications of historic climatic change. In: Kuna, M., Venclová, N. (Eds.): Whither archaeology? Institute of Archaeology, Prague, 121-132.

DAVIS, B. A. S., BREWER, S., STEVENSON, A. C. 2003: The temperature of Europe during the Holocene reconstructed from pollen data, Quaternary Science Reviews 22, 1701-1716.

DINCAUZE, D. F. 2000: Environmental Archaeology. Principles and Practice. Cambridge University Press, Cambridge.

DRESLEROVÁ, D. 2008: BRYSON, R. A., McENANEY DeWALL, K. A paleoclimatology workbook: high resolution, site-specific, macrophysical climate modeling. Hot Springs: The Mammoth Site of Hot Springs, SD, Archeologické rozhledy 60/4, 804-807.
DRESLEROVÁ, D. 2011: Přírodní prostředí a pravěké zemědělské společnosti (na území Čech) - Environment and prehistoric agricultural societies (in Bohemia). MS. Doctoral thesis. Deposited: Charles University, Prague.

ECKMEIER, E., GERLACH, R., GEHRT, E. 2007: Pedogenesis of Chernozems in Central Europe - A review, Geoderma 139, 288-299.

ELLWOOD, B.B., PETRUSO, K. M., HARROLD, F. B. 1997: HighResolution Paleoclimatic Trends for the Holocene Identified Using Magnetic Susceptibility Data from Archaeological Excavations in Caves, Journal of Archaeological Science 24, 569-573.

FINNÉ M. F., HOLMGREN, K. SUNDQUIST, H.S., WEIBERG, E., LINDBLOM, M. 2011: Climate in the eastern Mediterranean, and adjacent regions, during the past 6000 years. A review, Journal of Archaeological Science 38 (2011), 3153-3173.

FIRBAS, F., 1949, 1952: Spät- und nacheiszeitliche Waldgeschichte Mitteleuropas nordlich der Alpen. 1. Band: Allgemeine Waldgeschichte. Jena.. 2. Band: Waldgeschichte der einzelnen Landschaften. Jena.

GREENFIELD, H. J. 2010: The Secondary Products Revolution: the past, the present and the future, World archaeology 42(1): 29-54.

HALSTEAD, P., O'SHEA, J. (Eds.) 1989: Bad year economics: cultural responses to risk and uncertainty. Cambridge: University Press, Cambridge.

HAUPTMAN, I., KUKAL, Z., POŠMOURNÝ, K. (Eds.) 2009: Půda v České republice. Consult, Praha.

HEIRI, C., BUGMANN, H., TINNER, W. 2006: A model-based reconstruction of Holocene treeline dynamics in the Central Swiss Alps, Journal of Ecology 94, 206-216.

JÄGER, K. D. 2002: On the Holocene Water Balance in Central Europe and Several Historical Consequences. In: Wefer, G., Berger, W., Behre, K.-E. (Eds.): Climate Development and History of the North Atlantic Realm. Springer-Verlag, Berlin - Heidelberg, 369-375.

KALIS, A.J., MERKT, J., WUNDERLICH, J. 2003: Environmental changes during Holocene climatic optimum in Central Europe - human impact and natural causes, Quaternary Science Reviews 22, 33-79.

KOČÁR, P., DRESLEROVÁ, D. 2010: Archeobotanické nálezy pěstovaných rostlin v pravěku České republiky - Archeobotanical finds of cultivated plants in the prehistory of the Czech Republic, Památky archeologické $101,203-242$.

KOČÁR, P., DRESLEROVÁ, D., ŠEFRNA, L., CHUMAN, T., PONIŠTIAK, Š in prep.: Variety in cereal production in the Late Bronze and Early Iron Ages in relation to environmental conditions.

KYSELÝ, R. 2012 (in print): Paleoekonomika lengyelskeho obdobi a eneolitu Čech a Moravy z pohledu archeozoologie, Památky archeologické 103.

LANG, A., BORK, H. R. 2006: Past Soil Erosion in Europe. In: Boardman J., Poesen J. (Eds.): Soil erosion in Europe. John Wiley \& Sons, 465-476.

LEOPOLD, M., VÖLKEL, J. 2007: Soils and relief as a basis for a model to reconstruct the Iron Age land use pattern in the vicinity of a Celtic square enclosure in Southern Germany, Atti Soc. tosc. Sci. nat., Mem., Serie A, 112, 95-104.

MAGNY, M., HAAS, J.N. 2004: A major widespread climatic change around $5300 \mathrm{cal}$. yr BP at the time of the Alpine Iceman, Journal of Quaternary Science (2004) 19(5), 423-430.

MAGNY, M., LEUZINGER, U., BORTEMSCHLAGERM, S., HAAS, J. N. 2006: Tripartite climate reversal in Central Europe 5600-5300 years ago. Quaternary Research 65 (2006) 3-19.

MAISE, Ch. 1997: Der Klimageschichliche Hintergrund. In: Schibler, J., Hüstler-Plogmann, H., Jacomet, S. (Eds.): Ökonomie und Ökologie neolithischer und bronzezeitlicher Ufersiedlungen am Zürichsee: Ergebnisse der Ausgrabungen Mozartstrasse, Kanalisationssanierung Seefeld, AKAD/Pressehaus und Mythenschloss in Zürich. Monographien der Kantons, archäologie Zürich, no. 20. Zurich und Egg., 335-342.

MAISE, Ch. 1998: Archäoklimatologie - Vom Einfluss nacheiszeitlicher Klimavariabilität in der Ur- und Frühgeschichte, Jahrbuch der Schweizerischen Gesellschaft für Ur- und Frühgeschichte 81, 197-235.

McENANEY de WALL, K. 2007: Pfahlbauten, Habitations Lacustres, Lake Dwellings: Climate, people and the environment in the Neolithic and Bronze Age Alps. In: Bryson, R.A., McEnaney DeWall, K. (Eds.): Apaleoclimatology workbook: high resolution, site-specific, macrophysical climate modeling. The Mammoth Site of Hot Springs, Hot Springs, 91-102.

MENOTTI, F. 2001: “The missing period": Middle Bronze Age lakedwellings in the Alps. BAR 968, Oxford. 
MONTANARI, M. 2003: Hlad a hojnost. Dějiny stravování v Evropě. Lidové nakladatelství, Prague.

MORAVEC, D., VOTÝPKA, J. 2003: Regionalised Modelling. Charles University, The Karolinum Press, Prague.

NICOLUSSI, K., KAUFMANN, M., PATZELT, G. 2005: Holocene treeline variability in the Kauner Valley, central eastern Alps, indicated by dendrochronological analysis of living trees and subfossil logs, Vegetation Hist. Archaeobot. 14, 221-234.

OLSSON, F., LEMDAHL, G. 2009: A continuous Holocene beetle record from the site Stavsåkra, southern Sweden: implications for the last 10 600 years of forest and land use history, Journal of Quaternary Science 24/6, 612-626.

PÉTREQUIN, P., MAGNY, M., BAILLY, M. 2005: Habitat lacustre, densité de population et climat. L'exemple du Jura francais. In: Della Casa, P., Trachsel, M. (Eds.): WES'O4, Wetland Economies and Societies. 143, 168.

PRAŽÁKOVÁ, M., VESELÝ, J., FOTT, J. 2006: The long-term succession of cladoceran fauna and palaeoclimate forcing: A 14,600-year record from Plešné Lake, the Bohemian Forest, Biologia 61/ Suppl. 20, 387-399.

ROWLEY-CONWY 1984: The laziness of the short-distance hunter: the origins of agriculture in Denmark, Journal of Anthropological Archaeology 3:300-324.

SEPPÄ, H., NYMAN, M., KORHOLA, A., WECKSTRÖM, J. 2002: Changes of tree-lines and alpine vegetation in relation to post-glacial climate dynamics in northern Fennoscandia based on pollen and chironomid records, Journal of Quaternary Science 17, 287-301.

SEPPÄ, H., A. E. BJUNE, A. E., TELFORD, R.J., BIRKS, H. J. B., VESKI, S. 2009: Last nine-thousand years of temperature variability in Northern Europe, Clim. Past, 5, 523-535.

SCHIBLER, J., HÜSTER-PLOGMANN, H., JACOMET, S. 1997: Ökonomie und Ökologie neolitischer und bronzezeitlicher Ufersiedlungen am Zürichsee. Band A. Monographien der Kantonsarchäologie Zürich 20. Zürich-Egg.

SCHMIDT, R., KOINIG, K. A., THOMPSON, R., KAMENIK, Ch. 2002 A multi proxy core study of the last 7000 years of climate and alpine land-use impacts on an Austrian mountain lake (Unterer Landschitzsee, Niedere Tauern), Palaeogeography, Palaeoclimatology, Palaeoecology $187,101-120$.

SCHMIDT, B., GRUHLE, W., RÜCK, O. 2004: Klimaextreme in Bandkeramischer Zeit $(5300$ bis 5000 v. Chr.). Interpretation dendrochronologischer und archäologischer Befunde, Archäologisches Korrespondenzblatt 34/3, 303-308.

SCHMIDT, B., GRUHLE, W., ZIMMERMANN, A., FISCHER, T. 2005 Mögliche Schwankungen von Getreideerträgen: Befunde zur rheinischen Linienbandkeramik und Römischen Kaiserzeit, Archäologisches Korrespondenzblatt 35, Heft 3 (2005), 301-316.
SCHRØDER, N., PEDERSEN, L. H., BITSCH, R. J. 2004: 10,000 Years of Climate Change and Human Impact on the Environment in the Area Surrounding Lejre, Journal of Transdisciplinary Environmental Studies $3 / 1,1-27$.

SCHULTING, R. 2010: Holocene environmental change and the MesolithicNeolithic transition in northwest Europe: revisiting two models, Environmental Archaeology 15/2, 160-172.

SCHUMAN, B. 2012: Patterns, processes, and impacts of abrupt climate change in a warm world: the past 11,700 years, WIREs Clim Change 2012, 3, 19-43.

SPURK, M., LEUSCHNER, H.H., BAILLIE, M.G.L. 2002: Depositional frequency of German subfossil oaks: climatically and non-climatically induced fluctuations in the Holocene, The Holocene 12/6, 707-715.

THORNTHWAITE, C. W. 1948: An approach toward a rational classification of climate, Geographical Review 38 (1): 55-94.

TOLASZ, R., MIKOVÁ, T., VALERIÁNOVÁ, A., VOŽENÍLEK, V. (Eds.) 2007: Climate Atlas of Czechia. Czech Hydrometeorological Institute, Prague.

TURNEY, C. S. M., BAILLIE, M., PALMER, J. 2006: Holocene climatic change and past Irish societal response, Journal of Archaeological Science 33, 34-38.

VALSECCHI, V., TINNER, W., FINSINGER, W. 2006: Human impact during the Bronze Age on the vegetation at Lago Lucone (northern Italy), Veget. Hist. Archaeobot. 15, 99-113.

VESELÝ, J. 1998: Changes in vegetation of the Černé Lake area inferred from pollen analysis of lake sediment: period between $3400 \mathrm{BC}$ and 1600 AD, Silva Gabreta 2, 141-153.

VOIGT, R. 2006: Settlement History as reflection of climate change: the case study of Lake Jues (Harz mountains, Germany), Geografiska Annaler 88/2, 97-105.

WANNER, H., BEER, J. BÜTIKOFER, J. et. al. 2008: Mid- to Late Holocene climate change: an overview, Quaternary Science Reviews 27 (2008), 1791-1828.

ZÁDOROVÁ, T., CHUMAN, T., ŠEFRNA, 2008: Proposal for a method of colluvisols delimitation in chernozems regions. In: Soil and Water Research. ČAZV, Prague, 3: 215-222.

ZOLITSCHA, B., BEHRE, K.E., SCHNEIDER, J. 2003: Human and climatic impact on the environment as derived from colluvial, fluvial and lacustrine archives-examples from the Bronze Age to the migration period, Germany, Quaternary Science Reviews 22, 81-100.

ZVELEBIL, M., ROWLEY-CONWY, P. 1984: Transition to farming in northern Europe, Norwegian Archaeological Review 17, 104-128.

ŽÁK, K., LOŽEK, V., KADLEC, J. 2002: Climate-induced changes in Holocene calcareous tufa formations, Bohemian Karst, Czech Republic, Quarternary International 91, 137-152. 
